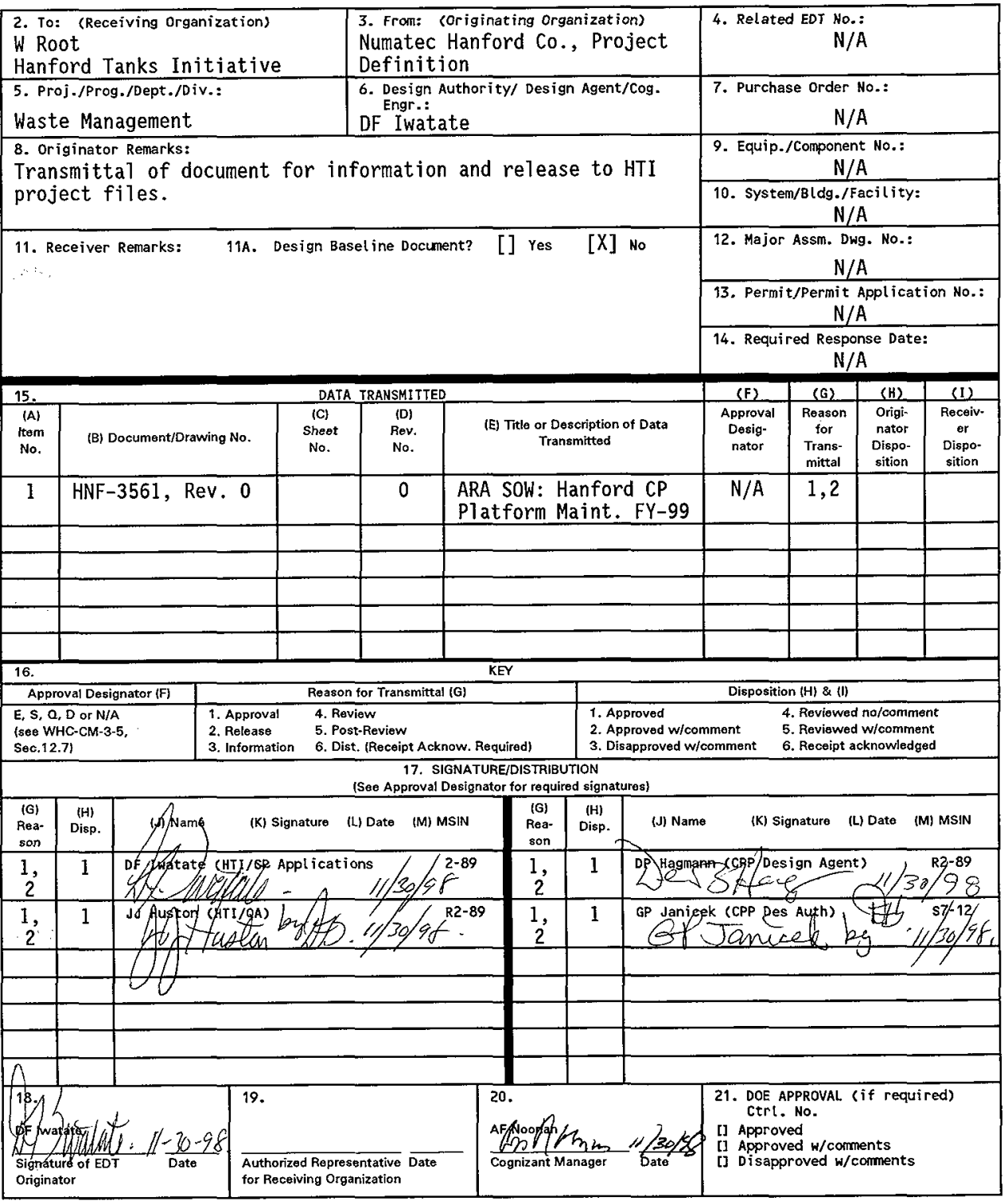




\title{
Maintenance of the Hanford Cone Penetrometer Platform During Fiscal Year 1999
}

DF Iwatate

Numatec Hanford Company, Richland, WA 99352-1300

U.S. Department of Energy Contract DE-AC06-96RL.13200

\author{
EDT/ECN: 622819 \\ UC: 2030 \\ Org Code: 73500 \\ CACN: 103262 (CP Probe Deployment Prep) \\ B\&R Code: EW3130010 \\ Total Pages: 12
}

Key Words: Single-She11 Tanks, cone penetrometer platform, CPP, maintenance, ARA

Abstract: This SOW describes services requested of Applied Research and Associates, Inc. (ARA), as a commercial provider of cone penetrometer equipment and services, to provide routine inspection and minimum preventive maintenance on the Hanford CP Platform (CPP) during Fiscal Year 1999. This SOW specifically pertains to the maintenance of the CPP and associated support equipment and is limited in scope to routine preventive maintenance and identification of any deficiencies. ARA is the original manufacturer of the CPP and will conduct this work following the vendor-prepared maintenance schedule.

(CPPFY9.CVR)

TRADEMARK DISCLAIMER. Reference herein to any specific comercial product, process, or service by trade name, trademark, manufacturer, or otherwise, does not necessarily constitute or imply its endorsement, recommendation, or favoring by the United States Government or any agency thereof or its contractors or subcontractors.

Printed in the United States of America. To obtain copies of this document, contact: Document Control Services, P.0. Box 950, Mailstop H6-08, Richland WA 99352, Phone (509) 372-2420; Fax (509) 376-4989.
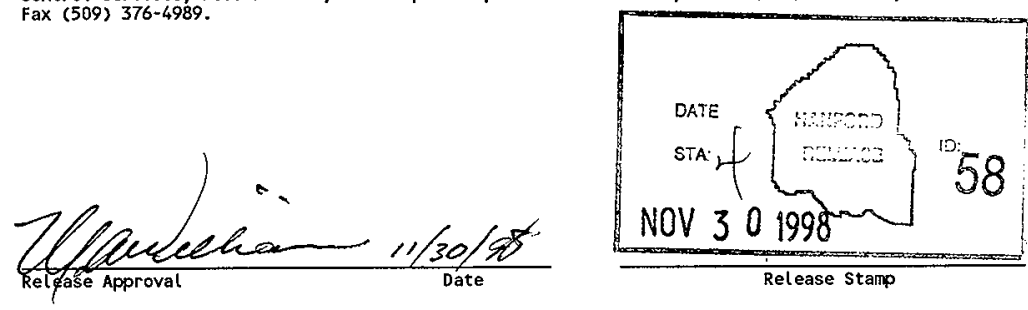




Maintenance of the Hanford Cone Penetrometer

Platform During Fiscal Year 1999

November 23, 1998

Project Hanford Document No. HNF-3561, Revision 0 


\section{INTRODUCTION}

This Statement of Work (SOW) specifically pertains to the maintenance of the Hanford Cone Penetrometer Platform (CPP) and associated support equipment: CPP Hanford Inventory No. WC58860; CPP Support Trailer HO-74-3470; CPP Generator HO-64-3833. The CPP is a large and complex piece of equipment that requires routine/periodic maintenance and general upkeep, according to a specific plan and schedule, in order to remain in a safe and ready-to-use condition. This SOW describes services requested of Applied Research and Associates, Inc. (ARA), as a commercial provider of cone penetrometer (CP) technique equipment and services, to provide routine inspection and minimum preventive maintenance on the CPP only during Fiscal Year 1999 (FY-99).

The CPP was originally designed and built during fiscal years 1995 and 1996 by ARA, the Department of Energy - Richland Office (DOE-RL), and the Hanford Tank Waste Remediation System (TWRS), under a contract that was managed by the TWRS organization. During FY-98 through FY-99, TWRS/Characterization Engineering (CE) has assigned user responsibility for the CPP to the Hanford Tanks Initiative (HTI) CP task manager. During the period of HTI use, that project will provide for the routine annual inspection and maintenance of the CPP and its support equipment following the maintenance schedule provided by Characterization Engineering (from the Vendor Information files for the CPP).

\section{OBJECTIVE}

The CPP is a non-mobile (i.e., no wheels or dedicated transport truck), CP pipe pushing unit that can be used to emplace pipe segments of several feet length and diameters up to 4 inches. A maximum pushing force of approximately 35 tons makes the unit particularly suited for soil/vadose zone tasks in the difficult, gravelly and boulder-laden soils of Hanford. The primary systems on the CPP are hydraulic activated and therefore require periodic activation through the extent of operational range in order to maintain minimum operable status. This SOW will put in place a contract to conduct this routine maintenance effort for the Hanford CPP for the period of FY-99. This SOW does not provide a contract or work scope for the conduct of repairs, modifications to CPP-related equipment, or changes to the vendor information (configuration controlled) files for the CPP. Such actions remain the responsibility and action for Hanford/TWRS/ Characterization Engineering. During the course of this work, should any equipment discrepancies or required repairs be identified, then the vendor/ARA will report these findings to the Buyers Technical Representative (BTR) and to the Design Authority for the CPP. Follow-up action on any findings will be pursued, as needed, through a separate contract and authorization process.

\section{SCOPE}

The vendor/ARA shall inspect and service the equipment in accordance with the CPP maintenance schedule that has been provided by TWRS/Characterization Engineering (Appendix A). At a minimum, this will include: inspection and servicing of all fluid reservoirs, grease to all Zerk fittings, performance of routine pre-operational equipment checks, and inspection of equipment for leaks and damage. In order to accomplish the requested work the vendor shall, as needed, make all necessary hydraulic and electrical hook-ups between the CPP and the support trailer. During operational checks the vendor shall start up the CPP and trailer components and operate all systems. Testing of hydraulic components shall include operation with a minimum of 10 complete cycles of full range movement. 
The vendor shall operate all CPP-related computer/software systems to verify that those programs are operable and functioning as designed (Note: this SOW does not include checkout and servicing of software/DAS related to specialized, custom CP probes that may be available for use with the CPP). Other systems such as the CPP HVAC and battery systems shall also be tested and cycled. The requested activities for this SOW are summarized in the following three major work elements (WEs):

WE-1 FY-99 CPP Maintenance Schedule/Plan

WE-2 Maintenance Activity Documentation and Activity Signoff

WE-3 CPP Configuration Control

\section{WORK ELEMENT 1: FY-99 CPP Maintenance Schedule and Plan}

Appendix A provides a copy of the vendor (i.e., ARA)-supplied maintenance schedule for the CPP and CPP support trailer. This copy of the maintenance schedule includes revisions and additions to the document that was originally provided with the CPP. Changes were made to address the change in mission for the CPP (from the initial "in tank" sampling task for which it was originally built). ARA will carry out the required routine, preventative maintenance, per the schedule, during the FY-99 period.

Since the CPP is planned for use during field activities throughout the year, ARA shall ensure that the maintenance activity is conducted during appropriate periods of opportunity and availability that will not interfere with the planned CPP deployment schedule. This will require coordination of the maintenance actions with the CPP field events and lead staff in order to minimize impacts to deployment schedules. In some instances it may be necessary to conduct CPP maintenance before or after the schedule's recommended time interval in order to work around field use periods. ARA shall prepare a plan for the conduct of this maintenance and submit to the Buyer immediately upon the start of the contract. Cold deployment activities are currently on-going. In-tank-farm, hot deployment, events are planned to start during the $2^{\text {nd }}$ quarter of FY-99.

During the course of this maintenance work, if components, conditions, deficiencies, and maintenance needs are identified as requiring work to correct, repair, or replace, then ARA shall bring those to the attention of the Buyer point-of-contact (POC) and the CPP Design Authority with written notice, including an estimate of CPP operational impacts and cost. The vendor shall not take action on such repair(s) or replacement activities until/unless directed to do so by the BTR/POC.

For maintenance activities requiring the use of specially calibrated tools and instruments, ARA is authorized to conduct such activities, as required by the maintenance schedule (Appendix A). ARA shall contact the CPP Design Authority and Design Agent prior to conducting these types of maintenance events.

\section{WORK ELEMENT 2: Maintenance Activity Documentation and Activity Signoff}

During the conduct of this work ARA shall maintain an up-to-date maintenance log for the CPP. Field/maintenance log entries shall provide correlation of work performed to the items in the maintenance schedule in order to document completion and chronology of activities. In those cases where hardware and repair activities are conducted, the log shall detail the work 
performed, including the cause (if known), correction or repair action, and information about any components installed or involved. Standards used for calibration work, and documentation of calibration instrument currency must be included in the field notes and summary reports for these activities. The maintenance $\log$, or a copy of that $\log$, shall be provided as a contract completion deliverable.

ARA shall provide a monthly summary to the BTR that includes a listing of all maintenance activities conducted in the previous month. A final, year-end summary (a compilation of all monthly reports) shall also be submitted as part of the contract completion deliverables. ARA shall ensure that all maintenance activities are announced to the Buyer prior to the start of work. Particular attention shall be paid to the documentation of activities that involve the revision of existing CPP baseline drawings (see: WE-3). Monthly activity summaries shall be submitted regardless of whether field work/maintenance was actually conducted. (see also: Section on Reporting and Communication). A final summary letter will be provided to the BTR/POC at the end of the contract period (9/30/99) summarizing the work done, identifying any needs, issues, concerns, and including [a copy of] all the monthly reports as appendixes.

\section{WORK ELEMENT 3: CPP Configuration Control}

In addition to routine task reporting (see section below, "Reporting and Communication") ARA will work with HTI staff to ensure that the CPP design baseline [documents and hardware] configuration control is maintained during the conduct of this work. Any CPP maintenance and/or inspection activities that impact the baseline design configuration of the CPP and support equipment must be brought specifically to the attention of the BTR/POC and the CPP Design Authority. Configuration control must be maintained for all CPP drawings, records, and CPP operating procedure changes or revisions, all of which are kept in the Hanford Vendor Information file (VI file) for the CPP.

Changes, revisions, additions, etc., to CPP VI file documents will remain the responsibility of Hanford staff and shall not be specifically undertaken by ARA without written direction from the BTR/POC and CPP Design Authority. If authorized to do so, this SOW does allow ARA to prepare (as needed), and maintain, configuration control of CPP-related procedures, drawings, and other configuration documentation (e.g., software) that are impacted/changed during maintenance activities. Any revised or new CPP documents resulting from the maintenance activities will be provided as deliverables at the conclusion of the task. ARA will coordinate this activity with HTI/Hanford CPP POC to ensure that applicable Project Hanford procedures are followed.

\section{PERIOD AND SCHEDULE FOR PERFORMANCE}

The period of performance for this work shall begin on the date of contract placement. All tasks and deliverables associated with this work request shall be completed no later than 9/30/99. ARA will conduct this work with consideration of the planned and ongoing field missions for the CPP.

\section{DELIVERABLES}


The deliverables for this work are primarily technical services that are provided through availability and access to vendor/ARA staff. Document deliverables are also required (as noted in the work element descriptions and summarized below), including: maintenance logs and field records related to the conduct of CPP maintenance, periodic status reports, and a final summary letter to the Buyer. The following list identifies the major deliverables for this work:

\begin{tabular}{|l|l|}
\hline \multicolumn{1}{|c|}{ Item } & \multicolumn{1}{|c|}{ When Needed/Chronology/Description } \\
\hline Maintenance Schedule/Plan for year & Immediately following the award of contract. Submit to BTR/POC. \\
\hline Monthly Reports & $\begin{array}{l}\text { Provide to BTR/POC within the first week of each month for the previous month. } \\
\text { Including work and budget summary and cost trend information. }\end{array}$ \\
\hline Special notice letters/memos & $\begin{array}{l}\text { Provide, as needed, to the BTR regarding significant equipment and/or repair tasks } \\
\text { that may have been identified and require attention beyond the scope of the SOW }\end{array}$ \\
\hline Maintenance log & Provide a copy of the maintenance log for all work conducted under this SOW \\
\hline Configuration control documents & $\begin{array}{l}\text { As required, prepare revised or new CPP documents (i.e., procedures, drawings, } \\
\text { other configuration documents, etc.) required as a result of maintenance activities, if } \\
\text { they impact the baseline design configuration per WE-3 of this SOW. }\end{array}$ \\
\hline Final summary letter & \begin{tabular}{l} 
Provide to BTR/POC at end of contract (i.e., on or before 9/30/99) \\
\hline
\end{tabular} \\
\hline
\end{tabular}

\section{MANAGEMENT AND RESPONSIBILITIES}

The responsible Hanford organization for management of this work scope is the Hanford Tanks Initiative project. The DOE/HTI POC is Ms. Deborah F. Iwatate (Numatec Hanford Corp./Phone: 509-376-8856/FAX: 509-373-1601/eMail: deborah_f iwatate@rl.gov). Ms. Iwatate will function as the BTR and liaison between HTI/Hanford staff and ARA. Ms. Iwatate will also provide technical oversight and comment, as needed or requested by ARA. A backup/secondary contact for this task will be Mr. A. F. Noonan of Pacific Northwest National Laboratories (PNNL) (509-372-6354). The HTI/Hanford CPP POC (and CPP acting Design Agent, is Mr. D. Hagmann (509-373-5761)).

ARA shall be responsible for providing all personnel necessary to support the requested work, and for providing required tools to conduct field maintenance. ARA shall also provide all materials, personnel, and office equipment necessary for the preparation of any written/report deliverable(s) related to this task. ARA shall provide internal management of their own resources during the completion of the task. The ARA POC for this work is Dr. Wesley Bratton (Phone: 509-371-9036/ eMail: wbratton@ara . com), ARA Pacific Northwest Branch, Richland, Washington, 99352).

\section{REPORTING AND COMMUNICATIONS}

Monthly task summaries will be provided by ARA during the course of this work, and discussed with the HTI BTR and POC for this task. These summaries may be in the form of telephone, FAX, face-toface, E-mail communication, or any combination of these methods. A summary of expenditures and cost trending shall also be provided to the HTI/Hanford technical POC at least monthly, for the prior 
month's performance period. These communications must be retained and provided at the completion of the work. Other documentation preparation information is provided in "SCOPE" Section, "Work Element \#2".

\section{QUALITY ASSURANCE}

All products and activities associated with the completion of this SOW will comply with ARA's documented corporate quality assurance program that is already planned, implemented, and maintained. The QA program will provide control over activities and products affecting quality, requested in this SOW, to an extent consistent with their importance. ARA is responsible for assuring that all such activities and products comply with the applicable QA policies and procedures defined in the [ARA] SOW, HNF-2881, current revision ("Preparation and Testing of CP Deployable Soil Multisensor and Multi-Sample Soil Sampling Probes: Phase II", dated August 12, 1998).

\section{PERMITTING AND REGULATORY COMPLIANCE}

Work conducted at the Hanford site must be in compliance with applicable regulatory requirements. ARA shall comply with all regulatory guidance and requirements as directed by the BUYER, and BTR, involved with this work scope. This responsibility includes the reporting and control of spills, leakage, and other waste that may be produced during the conduct of this work.

\section{SAFETY}

Work conducted at the Hanford site must be in compliance with applicable safety requirements. ARA shall comply with all safety guidance and requirements as directed by the BUYER, and BTR, involved with this work scope.

\section{REFERENCES}

None 


\section{APPENDIX A}

Maintenance Schedule for CPP, CPP Support Trailer, and Components 
MAINTENANCE SCHEDULE

FOR CPP SUPPORT TRAILER

AND COMPONENTS

Decon Water Pump

Screw Plug Water Immersion

Heater (Thermostatically

controlled)

Heater (Non-thermostatically

controlled)

Electric Generator

TASK

\begin{tabular}{|c|c|c|c|c|}
\hline \multirow[t]{2}{*}{ Electric Generator } & $\begin{array}{c}\mathrm{P} 4 \mathrm{CO} 6 \mathrm{O} \\
\mathrm{AO}\end{array}$ & CM $1855-66$ & Monthly & $\begin{array}{l}\text { Inspect all electrical connections to be sure they are clean, tight, and } \\
\text { properly insulated. Check ground straps. }\end{array}$ \\
\hline & & & 6 Months & $\begin{array}{l}\text { Check and clean intake and exhaust air screens. Inspect unit for } \\
\text { buildup of contamination on the windings. If necessary, internal } \\
\text { cleaning should be conducted by an authorized service facility. } \\
\text { Monitor and record insulation resistance with a } 500 \text { volt megohm } \\
\text { meter. The minimum acceptable reading is } 2 \text { megohms. If the reading } \\
\text { drops below the minimum, the generator should be dried and cleaned } \\
\text { by an authorized service shop. }\end{array}$ \\
\hline \multirow[t]{3}{*}{ Diesel Engine } & 4039 & T04039 T524536 & Daily & $\begin{array}{l}\text { Check coolant level BEFORE starting engine. Coolant level should be } \\
\text { at bottom of filler neck. If low, fill radiator with appropriate coolant } \\
\text { (see manual). }\end{array}$ \\
\hline & & & Daily & Check engine oil level with dipstick. If low, add SAE 15 W40 oil. \\
\hline & & & 100 hrs & Service fire extinguisher \\
\hline
\end{tabular}

Page 8 of 11 (CPP_SOW.99e) 
HNF-3561, Revision 0

\begin{tabular}{|c|c|c|c|c|}
\hline Diesel Engine & & & $250 \mathrm{hrs}$ & Service battery \\
\hline \multirow{19}{*}{$\begin{array}{l}\text { (This work will be performed by } \\
\text { Hanford site Transportation } \\
\text { Services upon direction/ notice } \\
\text { from the vendor/ARA (to the CPP } \\
\text { Design Authority and this SOW } \\
\text { BTR). The work will be } \\
\text { documented and followed by ARA } \\
\text { and summarized in the ARA } \\
\text { reporting deliverable.) }\end{array}$} & & & $250 \mathrm{hrs}$ & Change engine oil and filter. Use 15 W40 oil. \\
\hline & & & $250 \mathrm{hrs}$ & Check V-belt tension \\
\hline & & & $250 \mathrm{hrs}$ & Check PTO clutch adjustment \\
\hline & & & $400-1200 \mathrm{hrs}$ & $\begin{array}{l}\text { Initial valve clearance adjustment by an authorized servicing dealer. } \\
\text { Have serviced every } 1200 \text { hours after the initial } 400 \text { hour service. }\end{array}$ \\
\hline & & & $600 \mathrm{hrs}$ or $1 \mathrm{yr}$ & Lubricate PTO clutch levers and linkage \\
\hline & & & $600 \mathrm{hrs}$ or $1 \mathrm{yr}$ & Clean crank case vent tube \\
\hline & & & $600 \mathrm{hrs}$ or $1 \mathrm{yr}$ & Check air intake hoses and connections \\
\hline & & & $600 \mathrm{hrs}$ or $1 \mathrm{yr}$ & Replace fuel filter element \\
\hline & & & $600 \mathrm{hrs}$ or $1 \mathrm{yr}$ & Coolant solution analysis (see manual) \\
\hline & & & $600 \mathrm{hrs}$ or $1 \mathrm{yr}$ & Service air intake system \\
\hline & & & 600 hrs or $1 \mathrm{yr}$ & Check cooling system \\
\hline & & & 1200 hrs or 2 yrs & Perform engine tune-up \\
\hline & & & $1200 \mathrm{hrs}$ or $2 \mathrm{yrs}$ & Check and adjust engine speeds \\
\hline & & & $1200 \mathrm{hrs}$ or $2 \mathrm{yrs}$ & Adjust engine valve clearance \\
\hline & & & $1200 \mathrm{hrs}$ or $2 \mathrm{yrs}$ & Check fuel injection system \\
\hline & & & $1200 \mathrm{hrs}$ or $2 \mathrm{yrs}$ & Check crankshaft vibration damper \\
\hline & & & $1200 \mathrm{hrs}$ or $2 \mathrm{yrs}$ & Flush cooling system and replace thermostats \\
\hline & & & $1200 \mathrm{hrs}$ or $2 \mathrm{yrs}$ & Pressure test cooling system \\
\hline & & & As required & Inspect and service air cleaner elements \\
\hline Hydraulic Ofl Filter & $\begin{array}{c}\text { MN-LE- } \\
10\end{array}$ & - & $\begin{array}{l}200 \text { hrs, then } 1000 \\
\text { hrs }\end{array}$ & Change oil using Pennzoil AWS multi-viscosity oil \\
\hline Trailer & BT-U & $\begin{array}{l}\text { 4MWUF1- } \\
621 \text { TN000250 }\end{array}$ & As required & Confirm turn signal functioning, brake lights, and tire pressure \\
\hline
\end{tabular}




\begin{tabular}{|c|c|c|c|}
\hline $\begin{array}{l}\text { MAINTENANCE SCHEDUL } \\
\text { FOR PRIMARY CP PLATFO } \\
\text { COMPONENTS }\end{array}$ & & & \\
\hline $\begin{array}{l}\text { Uniterruptable Power Supply } \\
\text { (UPS) }\end{array}$ & & Monthly & Keep free of dust and dirt \\
\hline Electric Hoist & $2 \mathrm{Z668B}$ & Per Use & $\begin{array}{l}\text { WARNING: MAKE CERTAIN THAT POWER IS } \\
\text { DISCONNECTED BEFORE INSPECTION OR SERVICE. } \\
\text { ONLY A QUALIFIED SERVICE INDIVIDUAL SHOULD } \\
\text { PERFORM ELECTRICAL TROUBLE SHOOTING OR } \\
\text { MAINTENANCE. Check push-button station, brake, and limit } \\
\text { switch for proper operation (see manual) }\end{array}$ \\
\hline & & Per Use & $\begin{array}{l}\text { Check hooks for deformation, cracks, or other damage. Hooks having } \\
\text { a greater than } 1 \text { inch throat opening should be replaced }\end{array}$ \\
\hline & & Per Use & Check wire rope for wear, broken wires, kinks or twists \\
\hline & & Per Use & Check push-button cord and power cord for cuts or other damage \\
\hline & & Per Use & Check for loose bolts, screws or nuts \\
\hline & & Annually & $\begin{array}{l}\text { Check ENTIRE length of rope. Any of the following conditions merits } \\
\text { rope replacement: } \\
\text { a. More than } 4 \text { broken wires in any } 1 \text { inch section } \\
\text { b. Kinked,crushed, or otherwise distorted rope } \\
\text { c. Corrosion, chemical damage, or heat damage } \\
\text { d. More than one broken wire at the end connection point }\end{array}$ \\
\hline & & Per year & $\begin{array}{l}\text { Inspect for worn, corroded, cracked, or distorted parts including pins, } \\
\text { bearings, shafts, keys, and gears }\end{array}$ \\
\hline & & Per year & $\begin{array}{l}\text { Inspect supporting structure for continued ability to support imposed } \\
\text { loads }\end{array}$ \\
\hline & . & Per year & $\begin{array}{l}\text { Check for worn brake disc by measuring the brake air gap with a feeler } \\
\text { gauge (see manual). Brake gap larger than the allowable wear limit } \\
\text { may cause chatter or failure to release. }\end{array}$ \\
\hline Air Conditioner (2) & 7000 & As required & $\begin{array}{l}\text { All electrical work and/or inspection should be conducted by qualified } \\
\text { service personnel }\end{array}$ \\
\hline
\end{tabular}


HNF-3561, Revision 0

\begin{tabular}{|l|c|c|c|l|}
\hline Manual Lock Jacks for Y- & $\begin{array}{c}\text { WJ815- } \\
\text { Mavement }\end{array}$ & $\begin{array}{c}\text { J9517 } \\
\text { DF: } 316 \\
\text { DR: } 318 \\
\text { PF: } 317 \\
\text { PR: } 319\end{array}$ & 6 Months & Grease with white grease \#1200-1 at both lube points \\
& & & Annually & $\begin{array}{l}\text { Check lifting screw for end and side play. If end play seems excessive, } \\
\text { jack should be disassembled and inspected for worn parts (bearings, } \\
\text { bushings, or screw nuts) }\end{array}$ \\
\hline $\begin{array}{l}\text { Manual Lock Jacks for Y- } \\
\text { Movement }\end{array}$ & & & $\begin{array}{l}\text { Annually } \\
\text { be eliminated by removing bearing cap and removing shims as } \\
\text { required) }\end{array}$ \\
\cline { 2 - 5 } & & & 6 Months & Grease with Lubriplate grease \#1200-2 \\
\hline Rod Pad Eye Jacks & & & P Months & Grease tie bars for clamps \\
\hline Push System & Per year & Clean (see manual) \\
\hline Fan-Forced Heater & & Per year & Calibrate \\
\hline $\begin{array}{l}\text { Platform Pressure \& Load } \\
\text { Transducers }\end{array}$ & & & \\
\hline
\end{tabular}




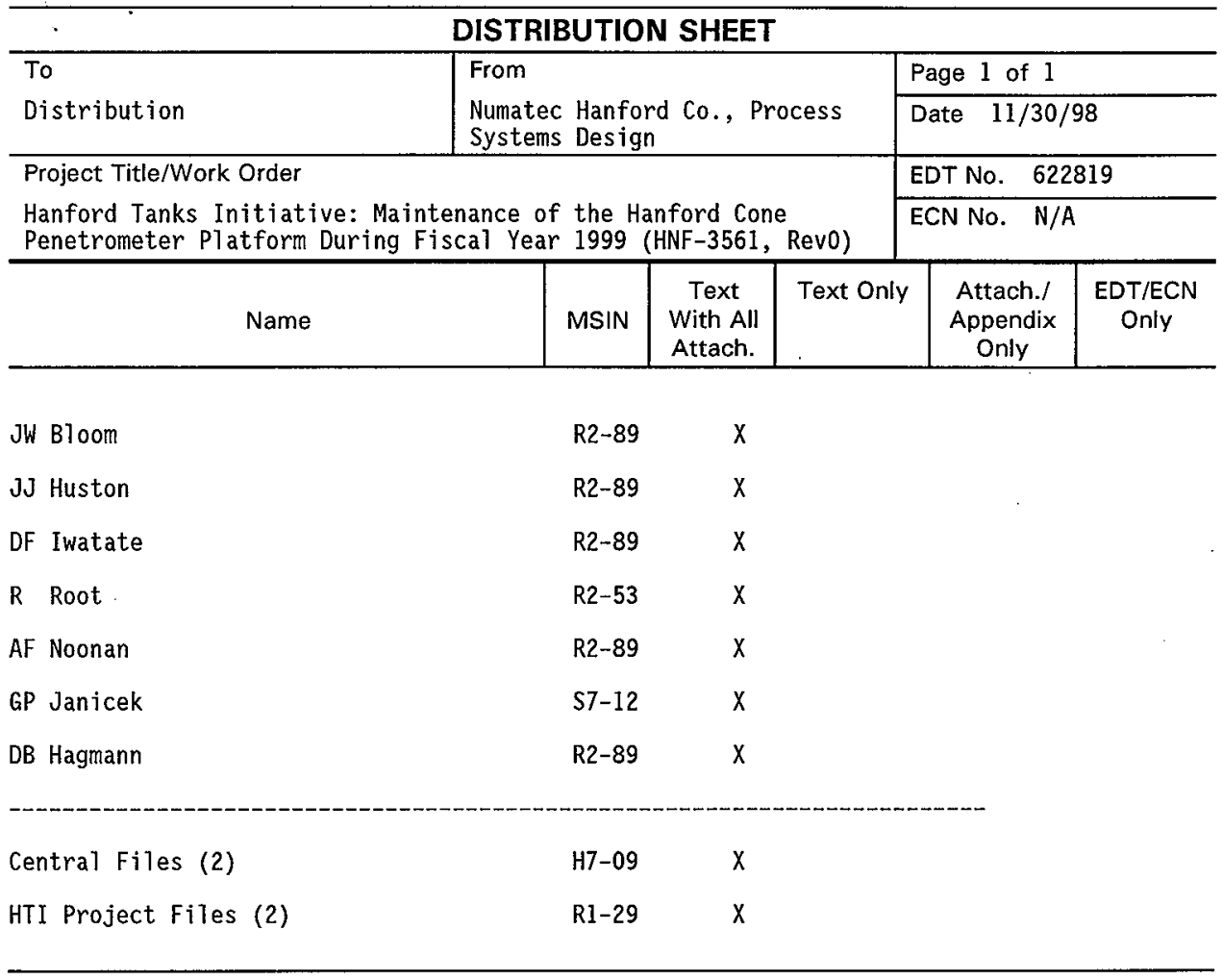

